\title{
Identification of Aquifer Properties in the Eastern Part of Kushtia District, Bangladesh
}

\author{
Md. Shahinuzzaman ${ }^{*}$, M. Nozibul Haque ${ }^{1}$, Khan M. Nasir Uddin1, M. Alibuddin² \\ ${ }^{1}$ Department of Electrical and Electronic Engineering, Islamic University, Kushtia, Bangladesh \\ ${ }^{2}$ Department of Physics, Meherpur Paura Degree College, Meherpur, Bangladesh \\ Email: *shahin.aece@gmail.com, mnhaque.iu@gmail.com, mnukhan@gmail.com, alibuddin.mpdc@gmail.com
}

How to cite this paper: Shahinuzzaman, M., Haque, M. N., Uddin, K. M. N., \& Alibuddin, M. (2020). Identification of Aquifer Properties in the Eastern Part of Kushtia District, Bangladesh. Journal of Geoscience and Environment Protection, 8 , 222-237.

https://doi.org/10.4236/gep.2020.811015

Received: October 4, 2020

Accepted: November 24, 2020

Published: November 27, 2020

Copyright $\odot 2020$ by author(s) and Scientific Research Publishing Inc. This work is licensed under the Creative Commons Attribution International License (CC BY 4.0).

http://creativecommons.org/licenses/by/4.0/

\begin{abstract}
The present study has been undertaken to depict spatial distribution of different aquifer parameters in the eastern part of Kushtia district through a detailed hydrogeological survey. For this investigation, 119 lithologs and 92 pumping test data have been used. These data have been processed, analyzed, interpreted and krigged for the spatial assessment of the aquifer properties viz. transmissivity, hydraulic conductivity, hydraulic diffusivity, specific yield, radius of influence, and specific drawdown. It is seen from the investigation that the transmissivity and hydraulic conductivity values obtained from the pumping tests of the wells are varying from $1811 \mathrm{~m}^{2} /$ day to $2568 \mathrm{~m}^{2} /$ day and $32.5 \mathrm{~m} /$ day and $61.5 \mathrm{~m} /$ day respectively, the hydraulic diffusivity being ranging from $181,143 \mathrm{~m}^{2} /$ day to $256,788 \mathrm{~m}^{2} /$ day. The estimated specific yield of $17.97 \%-23.46 \%$ supports that the area is dominated with coarse grained sands. This study reveals that the distribution of deep tube wells in the area are not within the radius of influence $(638-760 \mathrm{~m})$ each other, but few shallow and hand tube wells existed within the radius of influence. The estimated specific draw down is varying from $57 \mathrm{~m} /$ cumec to $126.1 \mathrm{~m} / \mathrm{cumec}$. From the overall analysis, it is found that the area is favorable for groundwater exploration.
\end{abstract}

\section{Keywords}

Groundwater, Aquifer, Pumping Test, Transmissivity, Hydraulic Conductivity, Hydraulic Diffusivity, Specific Yield, Radius of Influence, Specific Yield

\section{Introduction}

A life without water is unthinkable. As people increasing day by day, demand of water for domestic, irrigation and industrial use also increasing. But the supply 
of fresh water is limited and not available in full extent in all months of a year. On the other hand, most of the people depend on groundwater for drinking as is it found in the purest form compared to other freshwater sources.

Now people are forced to look for alternatives and use groundwater for irrigation and industry (Hoque et al., 2007) apart from drinking. Like many other natural resources, groundwater is being abstracted at an increasing rate all over the world and thus, exploitation of this useful resource is an important issue in the field of modern hydrogeology (Balek, 1989; Elango \& Sivakumar, 2005; Hoque et al., 2007). As the demand and needs of the population towards water is growing up in all the sectors, so the systematic planning of groundwater improvement using modern technique is fundamental for the proper management and utilization of this precious resource.

Groundwater is the principal source of drinking and irrigation water supplies in Bangladesh. About $97 \%$ of the population in Bangladesh used to rely on groundwater for drinking purposes while more than $70 \%$ of the total irrigated area is served with groundwater sources (BGS \& DPHE, 2001; Hasan et al., 2007). Development of the groundwater resource for irrigation and other uses is a vital component of the government's agricultural strategy to achieve food self-sufficiency in Bangladesh (MPO, 1991; Wahid et al., 2007; Shahid \& Hazarika, 2010), which is also highlighted in the national water management plan of the country (WARPO, 2001). Continuous decline of groundwater tables due to over-withdrawal has also been reported from some areas. In many localities, water mining occurs regularly which in turn forcing groundwater level to go down every year. Thus, the overall situation calls for urgent groundwater management for sustainable development. A lack of proper understanding of the groundwater system, in terms of resource utilization, is one of the major limitations to the effective management of groundwater resources in Bangladesh (Hoque et al., 2007). Thus, there is an urgent need to formulate a strategic plan for appropriate assessment and development of groundwater resources of the aquifer system under consideration adopting an integrated approach taking into account a wide range of ecological, socio-economic and scientific factors and needs.

The present study area is located in the upper side of the Ganges River dependent area, southwest of Bangladesh. This area is almost non-industrialized and dependent on agricultural system characterized by a number of agro-economical and socio-economic variables. The development of this area is closely related with the intensive use of its land with ensured irrigation. It has been anticipated that future demand of water for irrigation will be achieved through the development of groundwater resources of the area. But, the reduction of fresh water flows in the Ganges River during dry season in the recent years has limited the possibility of surface water resources development, which enhancing the people of the area to progressively shift to groundwater dependent irrigation-based agriculture (BBS, 2001; GOB, 2002). Therefore, assessment of hydrogeological condition of the study area is essential to identify the groundwater potentiality of the aquifer system for future development of the growing needs of 
increasing population.

The basic elements of groundwater investigation involve the delineation of the extent and thickness of the water-bearing zone along with the determination of aquifer properties. Distributions of sub-surface geologic units directly control the occurrence and movement of groundwater. The evaluation of sub-surface geologic formation is useful to understand the nature of groundwater-bearing zones. The conceptualization and characterizing of groundwater systems require quantification of the factors that govern the ability of the system to store and transmit groundwater. Aquifer properties may vary spatially because of geologic heterogeneity. Quantification of the aquifer properties is achieved primarily through pumping test. A pumping test is a field experiment in which a well is pumped at a controlled rate and water-level response (drawdown) is measured in one or more surrounding observation wells and in the pumped well (control well) itself; response data from pumping tests are used to estimate the hydraulic properties of aquifers.

The present study has been undertaken to demarcate spatial distribution of different aquifer parameters through a detailed hydrogeological survey. In this regard, 119 lithologs and 92 pumping test data have been processed, analyzed, interpreted and krigged for the spatial assessment of the aquifer properties like transmissivity, hydraulic conductivity, hydraulic diffusivity, specific yield, radius of influence, and specific drawdown. Krigging method is used for mapping the aquifer and well properties from point data for the spatial assessment of hydrogeology in the study area.

\section{Location and General Feature of Study Area}

Kushtia district is located on the northern side of the southwest part of Bangladesh. The present study area lies across three Upazilas (Sub-districts) namely, Khoksha and northern parts of Kushtia Sadar and Kumarkhali of Kushtia district comprising an area of $292.3 \mathrm{~km}^{2}$ as shown in Figure 1. It lies between the geographical coordinates of $23^{\circ} 43^{\prime} 45^{\prime \prime}-23^{\circ} 57^{\prime} 4^{\prime \prime} \mathrm{N}$ and $89^{\circ} 4^{\prime} 50^{\prime \prime}-89^{\circ} 22^{\prime} 5^{\prime \prime} \mathrm{E}$. This area consists of several villages, two upazila towns and one district town. The river-the Ganges (Padma) and its distributary, the Gorai are the major sources of surface water in the area. The Ganges is flowing in the extreme north-northeast sides of the area, where as the Gorai is flowing through the center from the northwest corner to the southeast corner. Most of the area is low lying floodplain formed by the alluvial soil.

The Ganges-Kobadak Irrigation Project (GKIP) or G-K Irrigation Project is a large surface irrigation system to serve the southwestern part of Bangladesh. It supplies the surface water from the Ganges River to the west and south sides of the study area, though this supply is not sufficient in dry months (March-June) due to the shortfall of water in the Ganges. The GKIP represents the major of Kharif-1 (March-June) season irrigation water supply (Alam, 1996). The reduction of the Ganges flow during dry season due to the withdrawal of the Ganges 


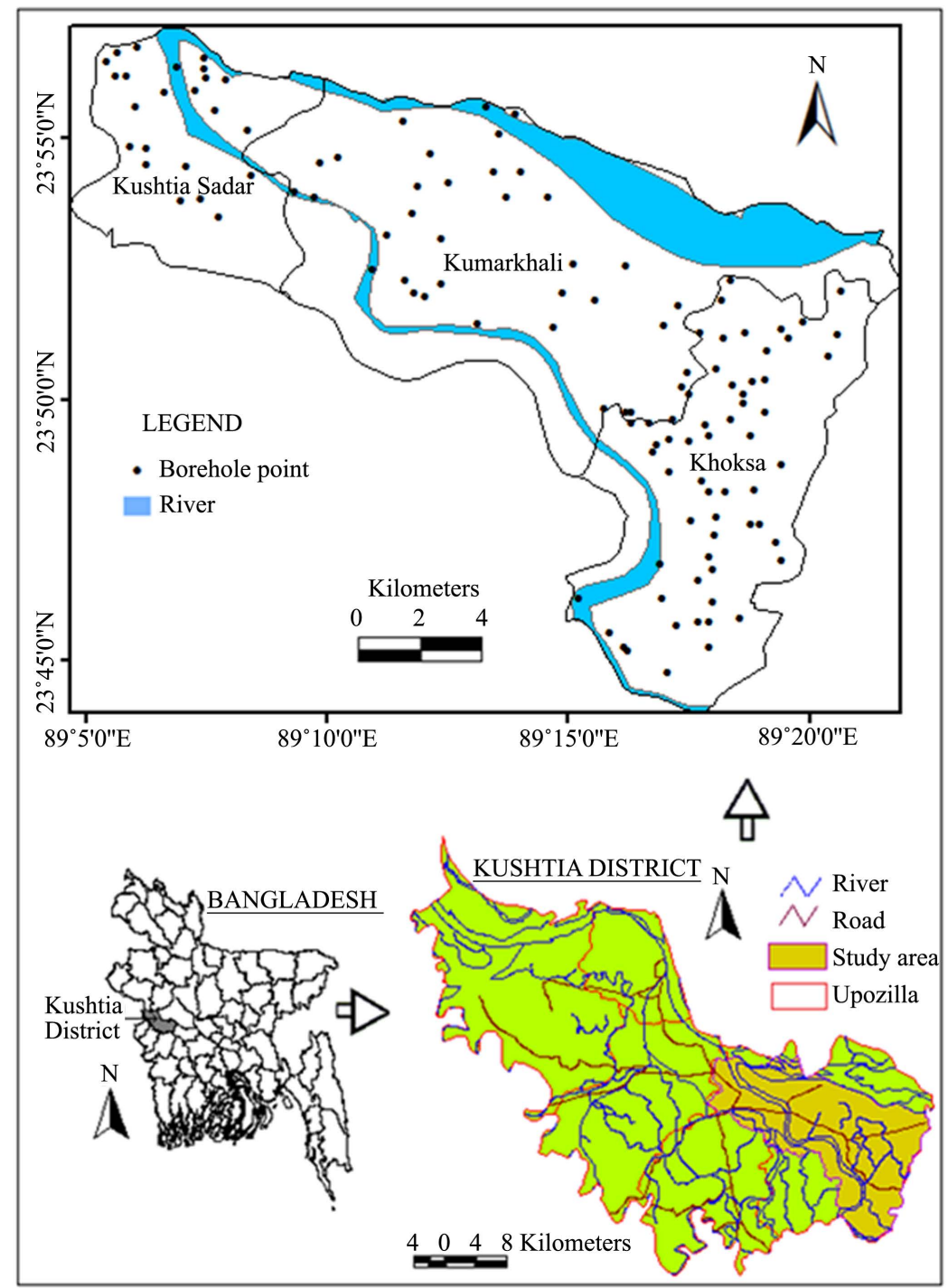

Figure 1. Location map of the study area.

water by the neighboring country has produced disastrous effect on irrigation as well as socio-economic development and ecological balance. This project is suffering from bitter experience of both the direct and indirect losses during the entire post diversion period (Wahiduzzaman \& Alam, 2006). Thus, the livelihood of about 20 million people near the GKIP is directly disrupted and threatened by the substantial water diversion in the upstream (Alam, 2010).

Several research works have been carried out by several authors in and around the study area. Groundwater potentiality was investigated in term of aquifer system (Haque \& Hasan, 2001; Haque et al. 2011), subsurface formation (Haque \& Hasan, 2002), hydrogeological properties (Islam et al. 2001), quantitative and qualitative assessment of aquifer system (Uddin et al. 2001; Shahinuzzaman et al., 2002), integrated hydrogeological and geophysical approach (Haque, 2008; Alibuddin, 2018), Geoelectrical sounding, borehole litholog and groundwater data (Haque et al., 2014). 
Further, groundwater flow and balance were studied for the assessment of groundwater abstraction (Sharmin et al., 2010a). For identification of groundwater bearing zones GIS (Sharmin et al., 2010b) and hydrostratigraphic analysis, (Alibuddin et al., 2014) have done as well. Almost all the previous researches were mostly focused on the overall assessment of hydrogeology of the area. No research has been carried out so far on the spatial distribution of aquifer properties of the area.

\section{Materials and Method}

Groundwater is one of the most important sources of water. The accumulation of groundwater in a particular area depends upon the presence of aquifers (Mahajan, 1989). Aquifer is a geologic unit that can store and transmit water at rates fast enough to supply reasonable amounts to wells. The aquifer must have two important properties, the ability to storage and to transmit water through the subsurface formation, those are defined as storage coefficient and transmissivity. Apart from these the other properties viz. porosity, permeability, hydraulic conductivity, specific yield etc. are also very important inherent properties of the aquifer. For the development of groundwater of any area, it is obligatory for the hydrogeologist to identify these properties with precession and to make further plans accordingly. Well hydraulics is a crucial topic in hydrogeology, since it is primary means of studying the aquifer properties (Lohman, 1972; King, 1982). Hydraulic properties of aquifer vary spatially because of geologic heterogeneity. Estimation of these properties allows quantitative prediction of the hydraulic response of the aquifer to recharge and pumping.

Pumping tests are the most suitable means for computing reliable and representative values of the hydraulic characteristics in aquifers (Kruseman \& De Ridder, 1994). The Bangladesh Agricultural Development Corporation (BADC), Kushtia conducted pumping tests from the production wells without having any observation well(s). This test is regarded as the "single-well test". Records of pumping test have been collected from the BADC, Kushtia for this work. The locations of wells meanwhile documented in Figure 1. In this study, an attempt has been made to determine some important aquifer properties viz. transmissivity, hydraulic conductivity, hydraulic diffusivity and specific yield using available 92 "single-well test" data. In addition to these, specific capacity, specific drawdown and radius of influence have also been determined.

\subsection{Transmissivity}

The aquifer transmissivity is a parameter that is fundamental to any groundwater flow characterization and allows a better evaluation of hydrogeological properties of an aquifer. It is defined as the rate at which water of prevailing kinematic viscosity is transmitted through a unit width and whole thickness of the aquifer in unit time under unit hydraulic gradient (Todd, 1980). The transmissivity $(T)$ of an aquifer is given by: 


$$
T=K b
$$

where, $K$ is hydraulic conductivity and $b$ is the aquifer saturated thickness.

In order to estimate the transmissivity for the present study area, the concept of specific capacity has been applied. Here, the relation between transmissivity and specific capacity established by Haque (2008) for a sedimentary formation adjoining the present study area lying in the same delta has been used. The linear empirical equation is given below:

$$
T=0.9083 S_{c}+1189.2
$$

Here, $S_{\mathrm{c}}$ is specific capacity which is defined as:

$$
S_{c}=Q / S_{w}
$$

where, $Q$ is pumping rate and $S_{w}$ is drawdown in pumped well at a specified time since pumping began.

The specific capacity used in Equation (2) has been estimated using three-step pumping test for the duration of 270 min, each step being equal duration of 90 min conducted by the BADC, Kushtia.

\subsection{Hydraulic Conductivity}

Hydraulic conductivity is a measure of how easily water can pass through soils or rocks (Thorbjarnarson et al., 1998). The higher the hydraulic conductivity, the faster the water flows at a given pressure (Bouwer \& Rice, 1976; Todd, 1980). The hydraulic conductivity, $K$ is usually computed from the transmissivity value and the corresponding saturated thickness of aquifer according to the following equation:

$$
K=T / b
$$

where, $T$ is the transmissivity and $b$ is the aquifer saturated thickness.

\subsection{Hydraulic Diffusivity}

Hydraulic diffusivity is defined as the ratio of transmissivity to the storage coefficient or, equivalently, hydraulic conductivity to specific storage, which can be written as:

$$
D=\frac{T}{S}=\frac{K b}{S}=\frac{K}{S_{s}}
$$

where, $D$ is hydraulic diffusivity, $T$ is transmissivity, $K$ is hydraulic conductivity, $b$ is saturated thickness of aquifer, $S$ is storage coefficient, and $S_{s}$ is specific storage $(S / b)$.

\subsection{Specific Yield}

The volume of water, expressed as a percentage of the total volume of the saturated formation, that can be drained by gravity is called the specific yield $S_{y}$ (Raghunath, 1987; Earle, 2006). The specific yield values proposed by Johnson (1967) (Table 1) are used in this study. The specific yield of any volume of 
Table 1. Assigned specific yield values for different lithology used for the study area (after Johnson, 1967).

\begin{tabular}{cccc}
\hline Materials & $\mathrm{S}_{\mathrm{y}}(\%)$ & Materials & $\mathrm{S}_{\mathrm{y}}(\%)$ \\
\hline Clay & 3 & Medium to coarse sand & 27.5 \\
Fine sand & 23 & Coarse sand & 27 \\
Fine-medium sand & 25.5 & Coarse sand gravel & 25.5 \\
Medium sand & 28 & - & - \\
\hline
\end{tabular}

geologic material can be obtained by summing up the specific yields of all the unit volume it contains. The weighted average specific yield can be written as:

$$
S_{y}=\frac{M_{1} m_{1}+M_{2} m_{2}+\cdots+M_{n} m_{n}}{M_{1}+M_{2}+\cdots+M_{n}}
$$

where, $M$ is the unit thickness and $m$ is specific yield of respective formation in percent.

\subsection{Radius of Influence}

When groundwater is pumped from a well a cone of depression occurs in aquifer (Figure 2). In an unconfined aquifer, this is an actual depression of the water levels. In confined aquifers, the cone of depression is a reduction in the pressure head surrounding the pumped well. The land area above a cone of depression is called the area of influence and the distance from the center of the well to the edge of the cone of depression is called the radius of influence. In the field, radius of influence gives an insight about the well spacing (Fletcher, 1998).

Radius of influence of pumping well gives an insight about the well spacing. In the present study the equation proposed by Bear (1979) is used to determine the radius of influence as:

$$
R=1.5 \sqrt{\frac{T}{S}}
$$

where, $R$ is the radius of influence for both confined and unconfined aquifer, $T$ and $S$ are transmissivity and storage coefficient respectively.

As the aquifer of the study area is unconfined in nature so the storage co-efficient, $S$ is chosen as 0.01 as mentioned by UNDP (1982) and MacDonald (1992).

\subsection{Specific Drawdown}

Drawdown $(D D)$ in a well is the difference between the initial static water level $(S W L)$ before pumping started and the pumping water level $(P W L)$, sometimes called dynamic water level, at any given time during the pumping.

$$
D D=S W L-P W L
$$

The specific capacity $(S C)$ of a well is defined as the Pumping flowrate $(Q)$ per unit of drawdown produced in the well. 


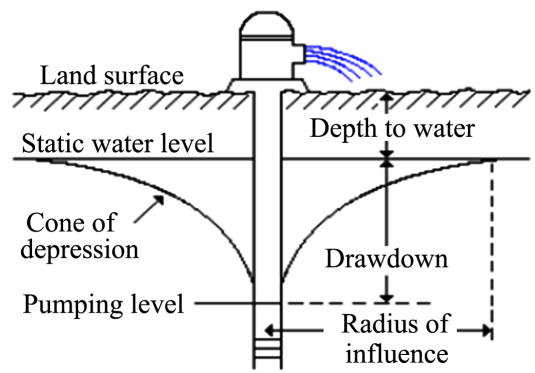

Figure 2. Diagrammatic section of a pumping well (after Raghunath, 1987).

$$
S C=Q / D D
$$

In well hydraulics the parameter, specific drawdown $(S D D)$ inverse of specific capacity,

$$
S D D=1 / S C
$$

is widely used for studying the aquifer properties.

\section{Result and Discussion}

\subsection{Transmissivity}

The transmissivity had been determined using Eden and Hazel (1973) method with the aid of StepMaster ${ }^{\mathrm{TM}}$ software. The discharging rates of the steps are $4893.15 \mathrm{~m}^{3} /$ day, $6116.43 \mathrm{~m}^{3} /$ day and $7339.72 \mathrm{~m}^{3} /$ day. Here, the final step $\left(3^{\text {rd }}\right.$ step) was taken into consideration. Transmissivity of all the wells of the study area has been estimated using the Equation (2) and depicted in Figure 3. The transmissivity values range from 1811 - $2568 \mathrm{~m}^{2} /$ day, the average being 2190 $\mathrm{m}^{2} /$ day. Most of the area covers within the transmissivity values from 2029 $\mathrm{m}^{2} /$ day to $2460 \mathrm{~m}^{2} /$ day, whereas there are few pockets having transmissivity greater than $2460 \mathrm{~m}^{2} /$ day and lower than $2029 \mathrm{~m}^{2} /$ day distributed in different parts of the area.

The aquifer in the study area is comprised of highly transmissible formations as described by Pitman (1982) for Bangladesh. High transmissivity of the area implies that the aquifers are capable of transmitting water for both irrigation and domestic purposes. The regions having high transmissivity value greater than $2460 \mathrm{~m}^{2} /$ day indicate an excellent groundwater condition, whilst the zones with moderate transmissivity of $1920-2460 \mathrm{~m}^{2} /$ day are very good for groundwater exploration. The region having low transmissivity value less than $1920 \mathrm{~m}^{2} /$ day may be considered as good for groundwater potential. It could be mentioned here that the area is favorable for groundwater development in terms of groundwater transmitting property provided.

\subsection{Hydraulic Conductivity}

Hydraulic conductivity is an important parameter in hydrogeology. This parameter is useful for groundwater management, protection and prediction of contaminants transport. The hydraulic conductivity determines the ability of the soil 


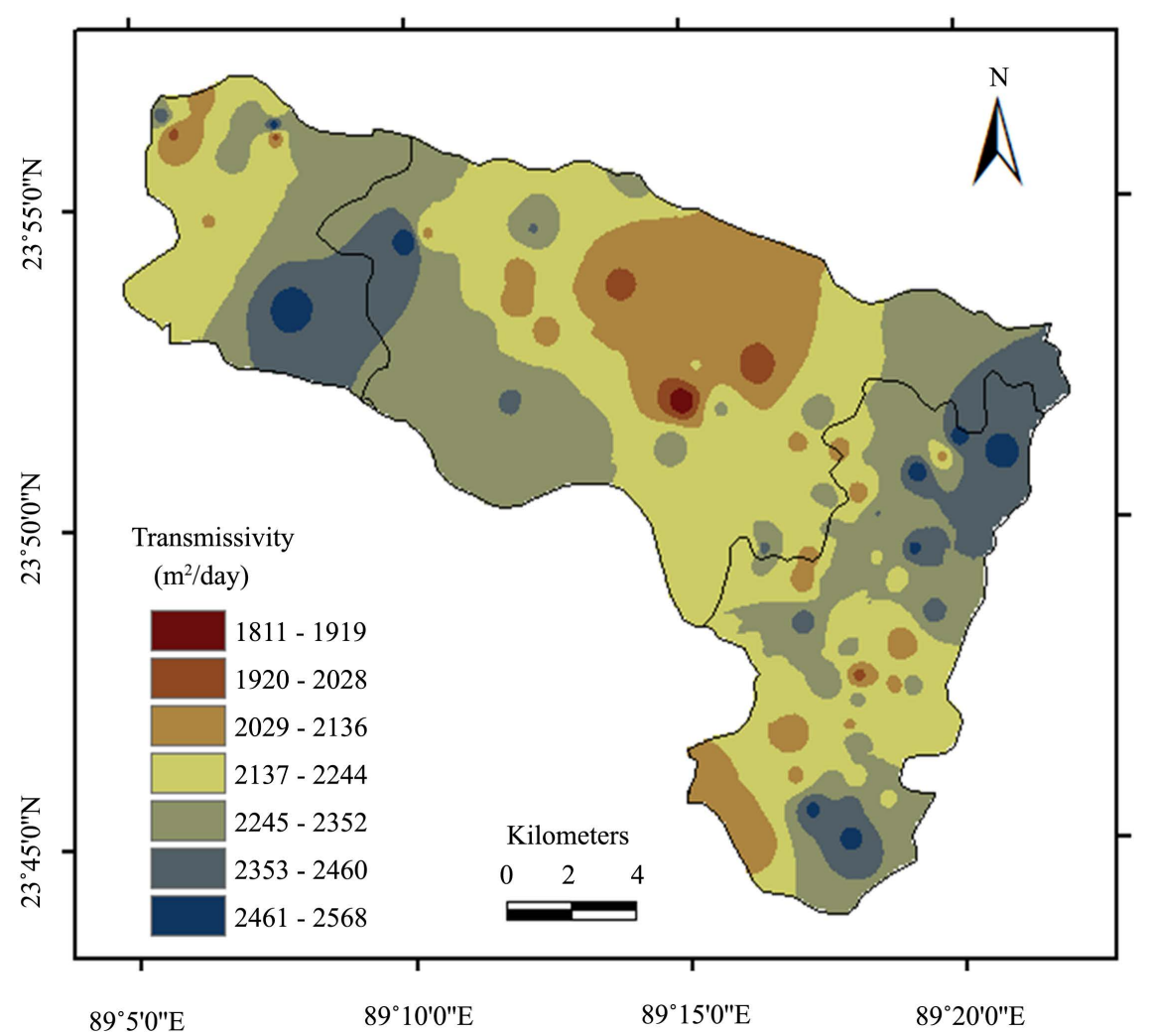

Figure 3. Spatial distribution of transmissivity in the study area.

fluid to flow through the soil matrix system under unit hydraulic gradient per unit time. The hydraulic conductivity depends on the soil grain size, the structure of the soil matrix, the type of soil fluid, and the relative amount of soil fluid (saturation) present in the soil matrix. Hydraulic conductivity varies with particle size for unconsolidated porous media; clayey materials exhibit low values of hydraulic conductivity, whereas sands and gravels display high values. Pumping test of wells is the most reliable method for estimating aquifer hydraulic conductivity. In this work, the hydraulic conductivity of the aquifer for each well has been estimated from the calculated transmissivity value and aquifer saturated thickness. The spatial distribution of hydraulic conductivity estimated using Equation (4) is illustrated in Figure 4. Hydraulic conductivity of the study area varies from $32.5 \mathrm{~m} /$ day to $61.5 \mathrm{~m} /$ day. Few small pouches of $32.5-40.7 \mathrm{~m} /$ day are distributed in different parts of the study area, but most part of the area with the value of $40.8-49 \mathrm{~m} /$ day specifies the favorability for groundwater exploration.

\subsection{Hydraulic Diffusivity}

The hydraulic diffusivity has a controlling role in the evaluation of groundwater flow behavior. It gives a measure of diffusion speed of pressure disturbances in groundwater system; large values of hydraulic diffusivity lead to fast propagation of fluids in aquifer. 


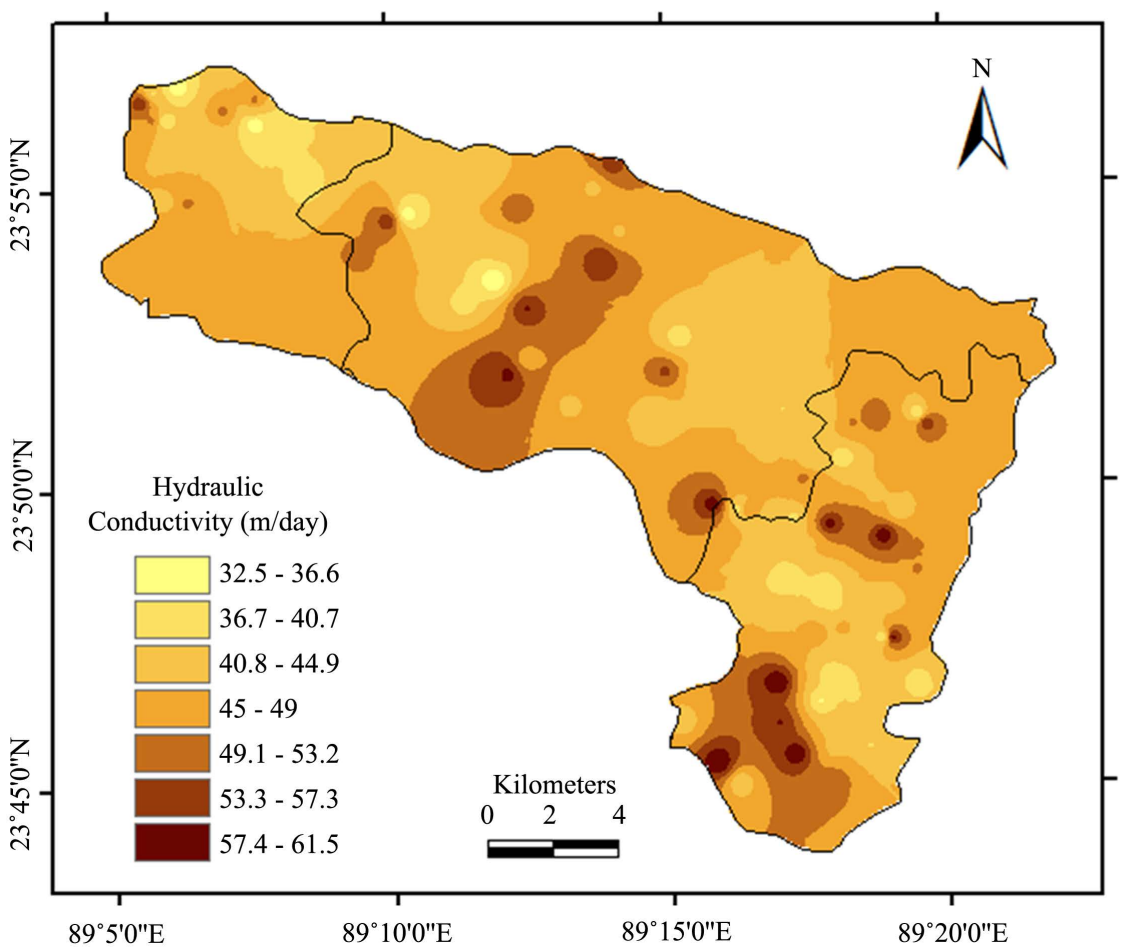

Figure 4. Spatial distribution of hydraulic conductivity in the study area.

The hydraulic diffusivity is an indicator of connectivity, higher values of diffusivity reflect higher degrees of flow and transport connectivity. The areal distribution of hydraulic diffusivity is useful in assessing the groundwater potential of aquifer. The Equation (5) is used to estimate the hydraulic diffusivity of the study area taking $T$ and $S$ into account. The value of storage co-efficient, $S$ is considered as 0.01 , since the aquifer of the area is unconfined in nature (UNDP, 1982; MacDonald, 1992). The spatial distribution of hydraulic diffusivity is presented in Figure 5. The hydraulic diffusivity varies from $181,143 \mathrm{~m}^{2}$ /day to $256,788 \mathrm{~m}^{2} /$ day. This parameter indicates the regions having higher values are comparatively favorable for groundwater development because of higher degrees of flow and transport connectivity. It can be noted that the hydraulic diffusivity map is the reflection of the map for transmissivity due to their direct relation.

\subsection{Specific Yield}

The spatial distribution of specific yield of the study area calculated using Equation (6) has been presented in Figure 6. Its values are, in general, representative of the ultimate amount of time for drainage. The specific yield of unconsolidated sediments of the area is related to the texture classes and within the classes, depending upon the composition i.e. the more sand in the sediments the higher the specific yield. Several zones have been demarcated in the area based on the range of its values varying from $17.97 \%$ to $23.46 \%$. There are some pouches with specific yield smaller than $20.33 \%$ distributed over the area, but most of the area 


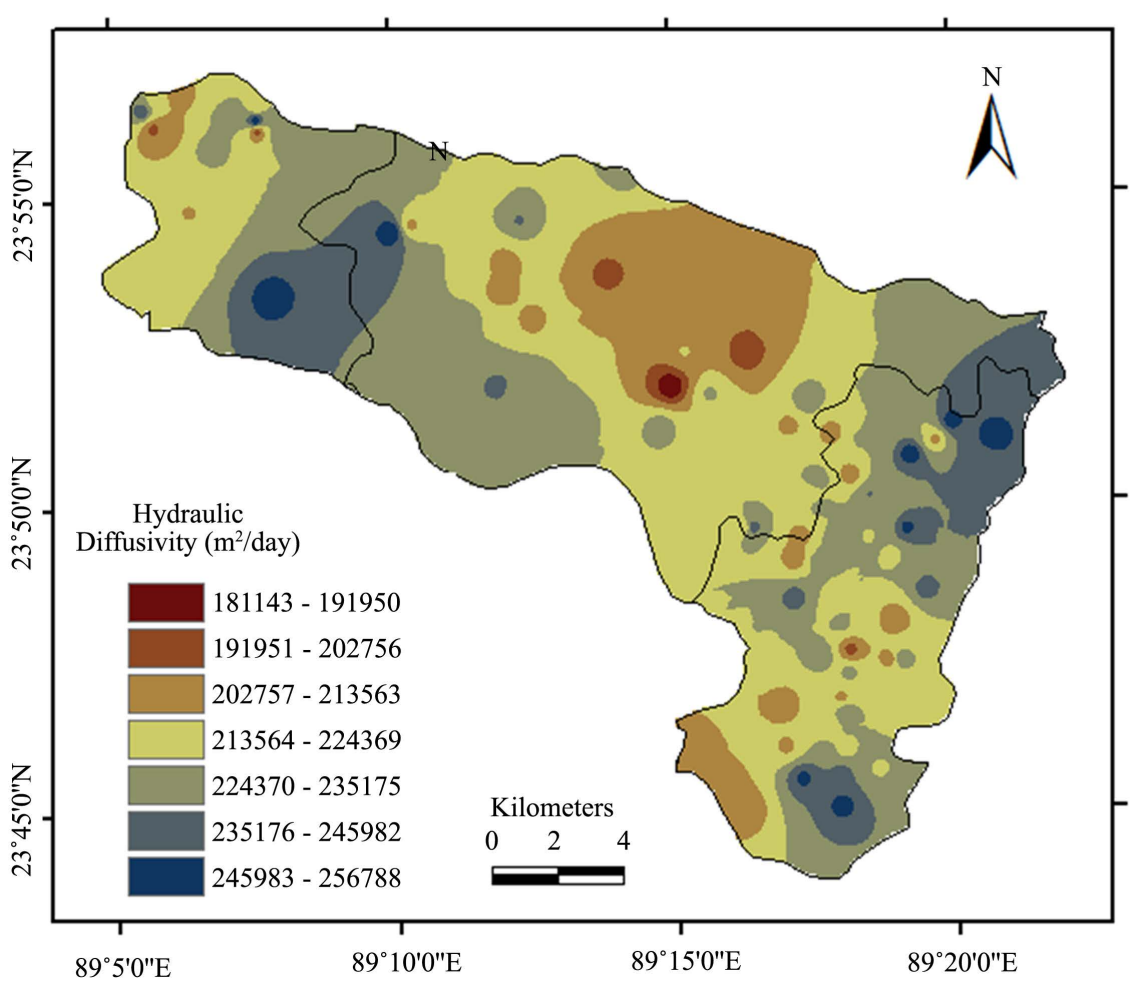

Figure 5. Spatial distribution of hydraulic diffusivity in the study area.

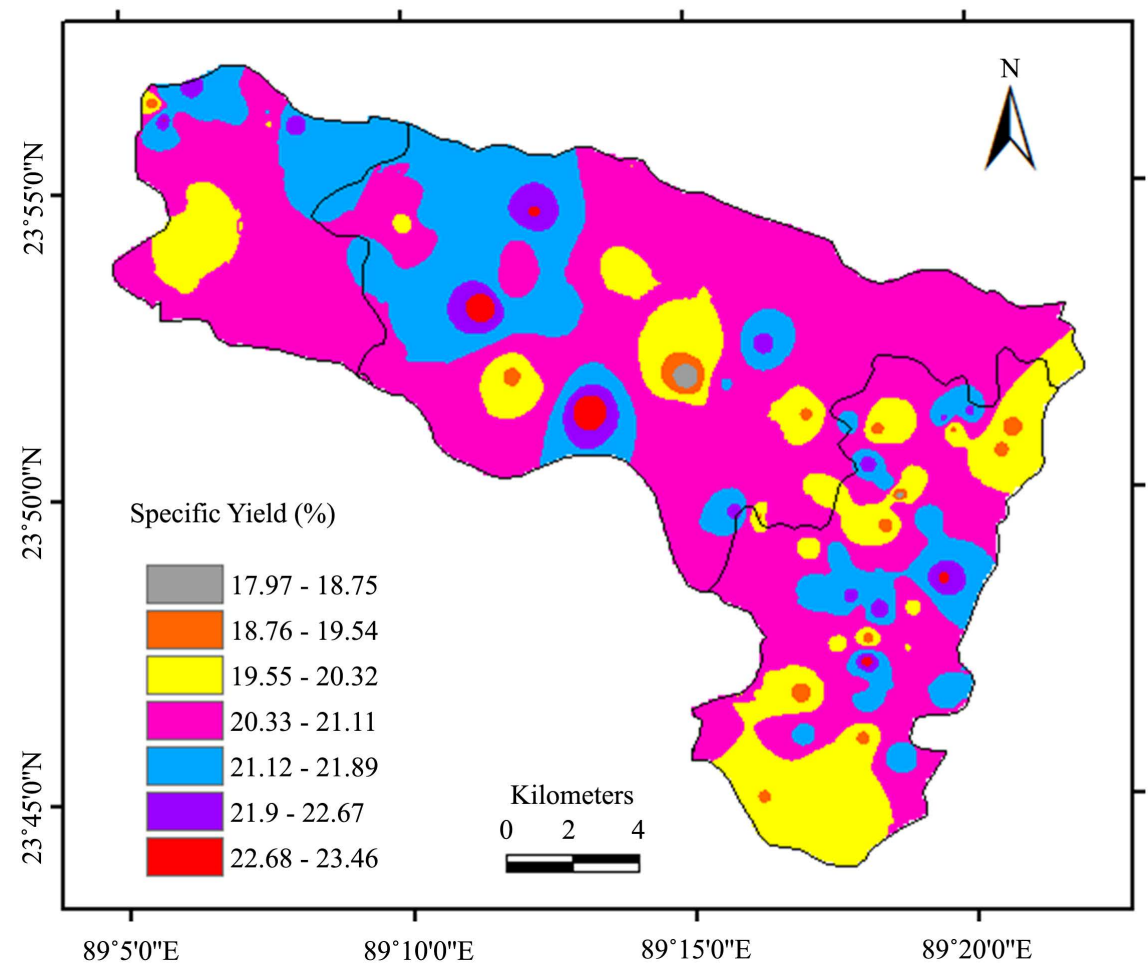

Figure 6. Spatial distribution of specific yield in the study area.

covers with the value ranging from $20.33 \%$ to $21.89 \%$ which indicates the suitability of the area for groundwater exploration. 


\subsection{Radius of Influence}

The spatial distribution of the radius of influence estimated using Equation (7) for the unconfined aquifer of the study area is presented in Figure 7. The estimated radius of influence is valid for the well pumped with a pumping capacity up to $7339.72 \mathrm{~m}^{3} /$ day, having a pipe diameter of $0.152 \mathrm{~m}$. The radius of influence of the area ranges from $638 \mathrm{~m}$ to $760 \mathrm{~m}$. The major part of the area covers with the value of $674-725 \mathrm{~m}$, while few pockets of $638-673 \mathrm{~m}$ and $625-760 \mathrm{~m}$ are distributed over the area.

\subsection{Specific Drawdown}

In this work, the specific drawdown has been estimated from the final step of three steps single-well pumping test data for each well of the study area and illustrated in Figure 8. In major part of the area, the specific drawdown varies from $57 \mathrm{~m} /$ cumec to $96.5 \mathrm{~m} /$ cumec except a small pouch located in the middle with specific drawdown ranging from $96.6 \mathrm{~m} / \mathrm{cumec}$ to $126.1 \mathrm{~m} / \mathrm{cumec}$. Since low drawdown represents a high specific capacity but high drawdown indicates low specific capacity, hence the wells having identical discharge rate will withdraw less amount of water from the wells placed in the regions of high specific drawdown than that of low value occupied zones.

\section{Conclusion}

Pumping test is the most reliable method for estimating aquifer properties.

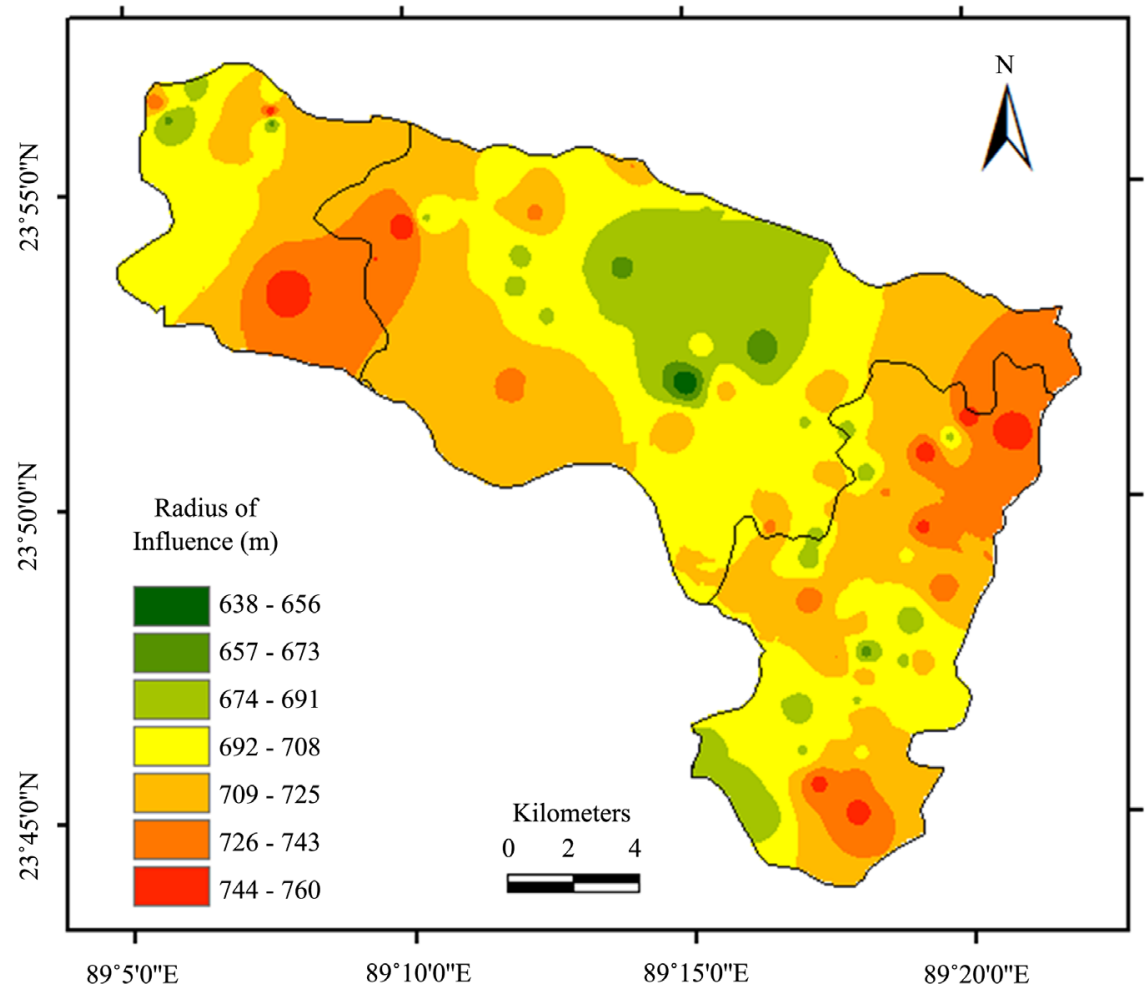

Figure 7. Spatial distribution of radius of influence in the study area. 


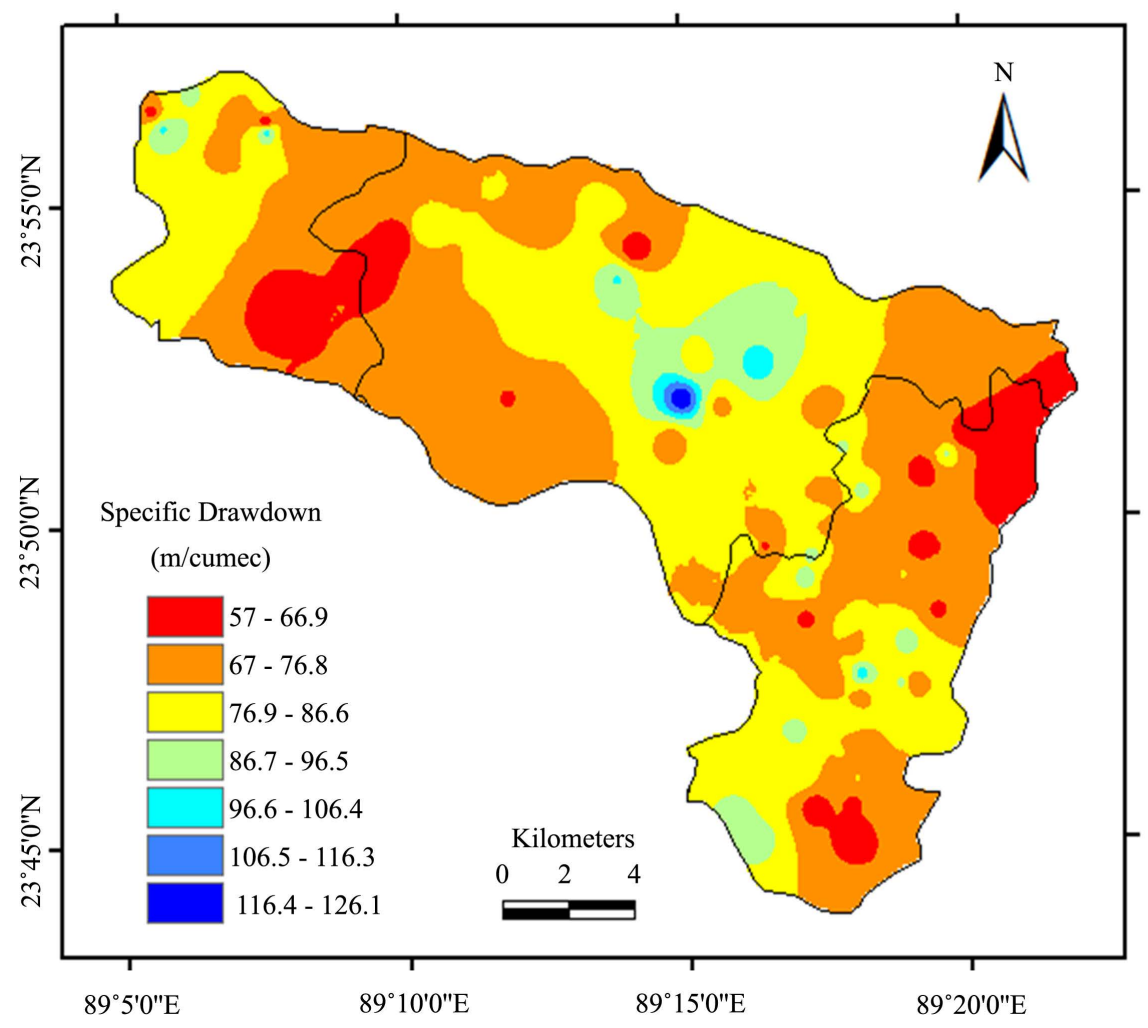

Figure 8. Spatial distribution of specific drawdown in the study area.

Transmissivity, an important aquifer characteristic, belongs to the study area is varying from $1811 \mathrm{~m}^{2} /$ day to $2568 \mathrm{~m}^{2} /$ day, the most area coverage is with the transmissivity of $2029-2460 \mathrm{~m}^{2} /$ day occupied in the middle, northwest and southeast zones. The estimated hydraulic conductivity lies between $32.5 \mathrm{~m} /$ day and $61.5 \mathrm{~m} /$ day. Another hydraulic parameter, the diffusivity varies from $181,143 \mathrm{~m}^{2} /$ day to $256,788 \mathrm{~m}^{2} /$ day. This parameter indicates the zone having higher values are comparatively favorable for groundwater development because of higher degrees of flow. The specific yield, in general, represents the ultimate amount of time for drainage. Several zones have been demarcated in the area based on the range of its values varying from $17.97 \%$ to $23.46 \%$. Well spacing has been proposed for the study area from the knowledge of the radius of influence estimated using an empirical formula under unconfined condition since the aquifer of the area is unconfined in nature. Observed minimum and maximum radius of influence of the area are $638 \mathrm{~m}$ to $760 \mathrm{~m}$ respectively. The distribution of the deep tube wells in the area is not within the radius of influence with each other, but there are shallow tube wells working for irrigation in and around the area of influence of deep tube wells as has been observed in the field. The specific drawdown of $57.0-126.1 \mathrm{~m} /$ cumec reveals that both the aquifer and abstraction wells of the area are in good condition. The overall range of the estimated hydraulic parameters of the aquifer system suggests that the area is hydrogeologically favorable for groundwater development provided the other conditions are satisfied. 


\section{Acknowledgements}

Authors are grateful to the Ministry of Science and Technology, Bangladesh for financial support to this research.

\section{Conflicts of Interest}

The authors declare no conflicts of interest regarding the publication of this paper.

\section{References}

Alam, M. M. (2010). Farakka Barrage and Its Impact on Agriculture and Environment: A Geo-Environmental Study in the Ganges-Kobadak Irrigation Project Area. Ph.D. Thesis, Gazipur: National University.

Alam, M. M. (1996). Agriculture in Ganges-Kobadak Irrigation Project: A Case Study of Alamdanga Irrigation SD-II (p. 104). Unpublished M.Sc. Thesis, Rajshahi: University of Rajshahi.

Alibuddin, M. (2018). Groundwater Potential Modeling in the Meherpur District of Bangladesh Using GIS through the Integration of Hydrogeological and Geophysical Data (p. 232). Ph.D. Thesis, Kushtia: Islamic University.

Alibuddin, M., Shahinuzzaman, M., Humayun Kabir, M., \& Haque, M. N. (2014). Hydrostratigraphic Analysis to Identify the Potential Groundwater Bearing Zones in the North of Meherpur District. Technical Journal of River Research Institute, 12, 1-12.

Balek, J. (1989). Groundwater Resources Assessment (pp. 13-14). Amsterdam: Elsevier Science Publishers.

BBS (2001). Population Census of Bangladesh: Bangladesh Bureau of Statistics. Statistic Division, Ministry of Planning, Government of the People's Republic of Bangladesh.

Bear, J. (1979). Hydraulics of Groundwater (p. 567). New York: McGraw-Hill.

BGS (British Geological Survey) and DPHE (Department of Public Health Engineering) (2001). Arsenic Contamination of Groundwater in Bangladesh. 2, Final Report, BGS Technical Report WC/00/19.

Bouwer, H., \& Rice, R. C. (1976). A Slug Test of Unconfined Aquifers with Completely or Partially Penetrating Wells. Water Resources Research, 12, 423-428. https://doi.org/10.1029/WR012i003p00423

Earle, S. (2006). Malaspina University-College. GEOL-304, HYDROGEOLOGY.

Eden, R. N., \& Hazei, C. P. (1973). Computer and Graphical Analysis of Variable Discharge Pumping Test of Wells. Institute of Engineers, Australia, Civil Engineering Transactions.

Elango, L., \& Sivakumar, C. (2005). Basics of Groundwater Flow. In L. Elango (Ed.), Chapter 1 in Numerical Simulation of Groundwater Flow and Solute Transport (pp. 1-14). Allied Publishers Pvt. Ltd.

Fletcher, F. W. (1998). Basic Hydrogeological Methods (p. 324). Technicom Publication.

GOB (2002). Second National Report on implementation of United Nations Convention to Combat Desertification. Bangladesh, Government of Bangladesh (GOB) Report, Dhaka: Ministry of Environment and Forests.

Haque, M. N., \& Hasan, M. A. F. M. R. (2001). Groundwater Potentiality in the Western Part of Kushtia District, Bangladesh. Journal of Applied Science and Technology, 2, 93-99. 
Haque, M. N., \& Hasan, M. A. F. M. R. (2002). Sub-Surface Formations and Groundwater Flow in Daulatpur and Bheramarathana of Kushtia District, Bangladesh. Journal of the Bangladesh National Geographical Association, 30, 41-54.

Haque, M. N. (2008). Delineation of Groundwater Potential Zones in the Western Part of Greater Kushtia District Based on Integrated Hydrogeological Geophysical Approach (p. 185). PhD Thesis, Rajshahi: University of Rajshahi.

Haque, M. N., Keramat, M., \& Shahid, S. (2011). Spatial Assessment of Aquifer Properties in a Soft Rock Area of Greater Kushtia District of Bangladesh. Journal of Applied Hydrology, XXIV, 9-18.

Haque, M. N., Keramat, M., \& Shahid, S. (2014). Groundwater Resource Evaluation in the Western Part of Kushtia District of Bangladesh Using Vertical Electrical Sounding Technique. ISH Journal of Hydraulic Engineering, 21, 97-110.

https://doi.org/10.1080/09715010.2014.981679

Hasan, M. A., Ahmed, K. M., Sracek, O., Bhattacharya, P., Brömssen, M. V., Broms, S., Fogelström, J., Mazumder, M. L., \& Jacks, G. (2007). Arsenic in Shallow Groundwater of Bangladesh: Investigations from Three Different Physiographic Settings. Hydrogeology Journal, 15, 1507-1522. https://doi.org/10.1007/s10040-007-0203-Z

Hoque, M. A., Hoque, M. M., \& Ahmed, K. M. (2007). Declining Groundwater Level and Aquifer Dewatering in Dhaka Metropolitan Area, Bangladesh: Causes and Quantification. Hydrogeology Journal, 15, 1523-1534. https://doi.org/10.1007/s10040-007-0226-5

Islam, M. S., Haque, M. N., \& Hasan, M. A. F. M. R. (2001). Hydrogeological Conditions in the Northern Part of KushtiaSadar Upazila of Bangladesh. Journal of Geo-Environment, 1, 79-89.

Johnson, A. I. (1967). Specific Yield-Compilation of Specific Yields for Various Materials. U.S. Geological Survey Water-Supply Paper, 1662-A.

King, H. W. (1982). Handbook of Hydraulics (p. 218). New York: McGraw-Hill Book Co.

Kruseman, G. P., \& De Ridder, N. A. (1994). Analysis and Evaluation of Pumping Test Data (3rd ed., p. 377). Wageningen: International Institute for Land Reclamation and Development.

Lohman, S. W. (1972). Groundwater Hydraulics (p. 708). U.S Geological Survey Professional Paper. https://doi.org/10.3133/pp708

MacDonald (1992). Northwest Bangladesh Groundwater Modeling Study. Sir. M. Macdonald and Partners Limited, Demeter House Station Road, Cambridge, England, Interim Report, In Association with Hunting Technical Services Ltd., El Street Way, Borehamwood, England.

Mahajan, G. (1989). Evaluation and Development of Groundwater (p. 316). New Delhi: Ashish Publishing House.

MPO (1991). National Water Plan Project-National Water Plan (Volume I, p. 109). Dhaka: Master Plan Organization.

Pitman, G. T. K. (1982). Aquifer and Recharge Evaluation of Bangladesh: Technical Note No. 8. UNDP/UNDTCD Groundwater Survey, BGD/74/009, BWDB, GWC, Bangladesh.

Raghunath, H. M. (1987). Groundwater (2nd ed., p. 563). New Delhi: Willey Eastern Ltd.

Shahid, S., \& Hazarika, M. K. (2010). Groundwater Drought in the Northwestern Districts of Bangladesh. Water Resources Management, 24, 1989-2006.

https://doi.org/10.1007/s11269-009-9534-y

Shahinuzzaman, M., Haque, M. N., \& Rahman, M. M. (2002). Groundwater Resource Evaluation in Khoksa Upaazila, Kushtia. Bangladesh Journal of Water Resource Re- 
search, 19, 69-79.

Sharmin, F., Alibuddin, M., \& Haque, M. N. (2010a). Groundwater Flow and Balance in the Area of Meherpur District, Bangladesh. Journal of Applied Science and Technology, 7, 47-54.

Sharmin, F., Alibuddin, M., \& Haque, M. N. (2010b). Groundwater Potential Modelling in the Northern Side of Meherpur Distric Using GIS. Journal of Applied Science and Technology, 7, 39-46.

Thorbjarnarson, K. W., Huntley, D., \& Mccarty, J. J. (1998). Absolute Hydraulic Conductivity Estimates from Aquifer Pumping and Tracer Tests in a Stratified Aquifer. Groundwater, 36, 87-97. https://doi.org/10.1111/j.1745-6584.1998.tb01068.x

Todd, D. K. (1980). Ground Water Hydrology (2nd ed., p. 535). Hoboken, NJ: John Wiley and Sons.

Uddin, M. J., Haque, M. N., \& Rahman, M. M. (2001). Simulation of Lithologs to Study the Groundwater Potentiality in Kumarkhali Upazila, Kushtia. Technical Journal, River Research Institute, 8, 30-44.

UNDP (United Nation Development Programme) (1982). The Hydrogeological Condition of Bangladesh, Groundwater Survey (p. 88). Technical Report DP/UN/BGD-74-0071, New York: UNDP.

Wahid, S. M., Babel, M. S., Das Gupta, A., \& Clemente, R. S. (2007). Spatial Assessment of Groundwater Use Potential for Irrigation in Teesta Barrage Project in Bangladesh. Hydrogeology Journal, 15, 365-382. https://doi.org/10.1007/s10040-006-0143-Z

Wahiduzzaman, A. K. M., \& Alam, M. M. (2006). Farakka Barrage: Its Impact on the Agricultural Scenario of Ganges-Kobadak Irrigation Project. Bhugal Patrika, 25, 172-185.

WARPO (Water Resources Planning Organization of Bangladesh) (2001). National Water Management Plan of Bangladesh. Final Report, Bangladesh: Water Resources Planning Organization. 